\title{
Voice as Form of Life and Life Form
}

\section{Abstract}

This paper studies the concept of form of life as central to ordinary language philosophy (as understood in Wittgenstein's, Austin's and Stanley Cavell's work): philosophy of our language as spoken; pronounced by a human voice within a form of life. Such an approach to Wittgenstein's later philosophy shifts the question of the common use of language - central to Wittgenstein's Investigations - to the definition of the subject as voice, and to the reinvention of subjectivity in language. The voice is both a subjective and common expression: it is what makes it possible for my individual voice, or claim, to become shared and for our forms of life to be intertwined with a life form.

\section{Introduction}

Throughout his work, Stanley Cavell's goal has been to "bring the human voice back into philosophy". For Cavell, the stakes of ordinary language philosophy (particularly Wittgenstein's and Austin's work) are to make it understood that language is spoken; pronounced by a human voice within a form of life. It then becomes a matter of shifting the question of the common use of language - central to Wittgenstein's Philosophical Investigations (PI) toward the less-explored question of the definition of the subject as voice, and the re-introduction of the voice into philosophy as a redefinition of subjectivity in language, as a form of life. 
A number of issues arise from this approach to voice. To say that the subject is voice shifts the classical problem of expression to the question of the adequacy between subject and voice. There is also the question of the "we". The voice is both a subjective and a general expression: it is what makes it possible for my individual voice to become shared. In voice, there is the idea of a claim. The singular claims a shared, common validity.

There is also a political question that arises: the question of representation and the subject's expression by his or her community - and, inversely, the community's expression by the subject. Here, Cavell's thought encounters Emerson's, as well as a philosophy of democracy and a politics of voice: find one's voice in politics, express what?

\section{Subject, Expression, and Voice}

The philosophical interest in turning to "what we say" appears when we ask ourselves not only what it is to say, but what this we is. How do I, myself, know what we say in such or such circumstance? In what way is the language that I speak, inherited from others, mine? Cavell hears the echo of these questions in the opening lines of the Philosophical Investigations (which begins with the quote from Augustine: because, says Cavell, "all my words are those of an other". Language is an inherited form of life).

1. Augustinus, in den Confessiones I/8: cum ipsi (majores homines) appellabant rem aliquam, et cum secundum eam vocem corpus ad aliquid movebant, videbam, et tenebam hoc ab eis vocari rem illam, quod sonabant, cum eam vellent ostendere. Hoc autem eos velle ex motu corporis aperiebatur: tamquam verbis naturalibus omnium gentium, quae fiunt vultu et nutu oculorum, ceterorumque membrorum actu, et sonitu vocis indicante affectionem animi in petendis, habendis, rejiciendis, fugiendisve rebus. Ita verba in variis sententiis locis suis posita, et crebro audita, quarum rerum signa essent, paulatim colligebam, measque jam voluntates, edomito in eis signis ore, per haec enuntiabam.

I. Augustine, Confessions, I. 8: When they (my elders) named some object, and accordingly moved toward something, I saw this and I grasped that the thing was called by the sound they uttered when they meant to point it out. Their intention was shown by their bodily 
movements, as it were the natural language of all peoples: the expression of the face, the play of the eyes, the movement of other parts of the body, and the tone of voice which expresses our state of mind in seeking, having, rejecting, or avoiding something. Thus, as I heard words repeatedly used in their proper places in various sentences, I gradually learnt to understand what objects they signified; and after I had trained my mouth to form these signs, I used them to express my own desires. $(P I, \$ 1)$

Here we find all the themes of the Investigations: language learning; community; meaning; desire. But, at the same time, the subject, voice, and expression.

Wittgenstein takes up the idea of confession again at the end of the second part of the Investigations. In the Investigations, speaking is defined in the mode of confession, which is defined as external (it is that on the basis of which one judges the inner: there is nothing else):

There is indeed the case where someone later reveals his inmost heart [sein Innerstes] to me by a confession: but that this is so cannot offer me any explanation of outer and inner, for I have to give credence to the confession.

For confession is of course something exterior. (Zettel: 100, \$558)

It is not a matter of expressing a secret, or something hidden. "Hidden" is false, for the inner, quite simply, hides nothing. As Cavell asks:

But why do we think of a state (of mind, say) as inner? Why do we think of the meaning of a (some particular) poem as inner? (And mightn't we think of some states of physical objects as inner? Perhaps not its hardness; but its magnetic power? or its radioactivity?) What pertains to the soul is thought of as inner. But why? "Inner" means, in part, something like inaccessible, hidden (like a room). But it also means pervasive, like atmosphere, or the action of the heart. What I have in mind is carried in phrases like "inner beauty", "inner conviction", "inner strength", "inner calm". This suggests that the more deeply a characteristic pervades a soul, the more obvious is it. (Cf. envy as a sharp feeling and a state of the soul.)

[...] I feel: That "something or other" is in there is what "outward" says. In itself the word deprives the notion of a criterion of none of its 
power; and adds none to it. But a false idea of the inward produces a false idea of the outward. (Cavell 1979: 99-100)

I do not know - not because I am not certain or because there is doubt, but because there is no place to know. Skepticism is thus less a cognitive problem (the possibility of knowing the world or others, or of having access to the other's inner) than it is a symptom - the symptom of my refusal of expression. The question of knowledge of the other doubles and masks the question of my own accessibility (to others and to myself). There is no secret, "nothing is hidden." Not because everything is external, but because the only secrets are those we do not wish to hear; and because what is private is only that which we do not want to know - or which we refuse to access or express.

But following Cavell we may also reverse more radically the investigation of "private language". "The problem is not being unable to express or exteriorize what I have "inside"; to think, or feel something without being able to say it (a problem Wittgenstein dealt with in the Tractatus). The problem is the opposite: not meaning what I say. Here, perhaps, lies one source of the idea of private language: not a difficulty in knowing (it is not, as Wittgenstein repeats, a problem of knowledge), but rather a refusal, even a fear, of meaning; a fear of accessing - or exposing oneself to - the outside. Hence the seductiveness of the idea of a secret: we prefer to think that what is private to us is secret rather than recognize the very nature of this privacy, which is to be bound up in a structure of expression.

It is once again the very possibility of expression (linguistic or other), and of pretending, that defines subjectivity. In the Investigations, particularly in the passages concerning private language this possibility is imagined in terms of skepticism concerning not only access to others, but to oneself. This disquiet is represented by the various moments in which Wittgenstein imagines the impossibility, or dispossession, of speech: is it I who speak with my mouth (or is it an other, or even others)?

\footnotetext{
${ }^{1}$ For a full analysis, see S. Laugier, "The Myth of the Outer: Wittgenstein's redefinition of subjectivity” in Moyal-Sharrock (ed.) 2007, pp. 151-173.
} 
What about my own case: how do I myself recognize my own disposition? - Here it will have been necessary for me to take notice of myself as others do, to listen to myself talking, to be able to draw conclusions from what I say! (PI, II, x)

Here the myth of the private gives way, as Cavell says, to a myth of inexpressiveness. This idea of inexpressiveness proves to be the very anxiety of expression; the anxiety of the very naturality of the passage from inner to outer.

So in the end when one is doing philosophy one gets to the point where one would like just to emit an inarticulate sound. (PI \$261)

Here Wittgenstein imagines the temptation to, or mythology of, not silence but inexpressiveness. As if the passage to the outside were a loss of control over what I mean and thus ultimately as if an inexpressive, "inarticulate sound" were sometimes preferable to an expression charged with meaning. To accept expression is to accept the reality of the (corporal) exteriority of meaning. "The human body is the best picture of the human soul" (PI II, iv) - not because it represents it (and what would that mean?), or possesses it, but insofar as it gives it expression. This - like the redefined inner/outer relation - is part of our form of life (is it what is given), what must be "accepted." To recognize this inner/outer relation

is equally to acknowledge that your expressions in fact express you, that they are yours, that you are in them. This means allowing yourself to be comprehended, something you can always deny. Not to deny it is, I would like to say, to acknowledge your body, and the body of your expressions, to be yours, you on earth, all there will ever be of you... (Cavell 1979: 383)

Such recognition would mean accepting expression (Ausdrück) as identically inner (it expresses me) and outer (it exposes me). The very nature of subjectivity as reinvented by Wittgenstein is revealed in this final identity: the subject is certainly subject of/to language Wittgenstein demonstrates this in every possible way in the Investigations - but in the sense in which he or she is subject of (to) expression. Taken together, Wittgenstein's remarks on the philosophy of psychology seem to give voice to this problematic subject. 
Now this subject of language indeed appears as voice, and not as a "vocal voice but an inner voice. Is an inner voice inner? Several of Wittgenstein's remarks raise this question.

You know that you are lying; if you are lying, you know it. An inner voice, a feeling tells me? Might this feeling not deceive me?

Does a voice always tell me? And when does it speak? The whole time? (RPP I: 82, \$779)

One might suppose, then, that the subject in Wittgenstein exists exactly like this voice - in and through language. But what defines this voice is precisely that it is at once identically inner (I speak it) and outer (I hear it). The voice can be, as we will see, the common voice of our understanding (Übereinstimmung; PI \$241); the voice of our agreement in language - but it is my voice, or one of my voices, in the trivial (factual) sense in which my body is mine. I have "a different relation" to it (PI, p. 192).

The fact that the voice is inseparably inner and outer means that it is obviously a voice that reassures me neither of my identity nor of my thought - nor of anything whatsoever (as soon as the voice is voice, it is expression, and escapes me). In other words, there is no $I$ to whom the voice speaks.

The subject thus defined by the voice is not a limit or a point, nor a center, nor an interlocutor - to cite several traditional representations - but, Wittgenstein suggests, a "gaping space" [Ein löchriger Raum]:

One language-game analogous to a fragment of another. One space projected into a limited extent of another. A "gaping space" [Ein löchriger Raum]. (For “inner and outer”.) (Z \$648)

We see that to define the subject as subject of language is less a way of overcoming skepticism than a way of reformulating it. In Cavell's reading of Wittgenstein, skepticism is the symptom of a more general impossibility: the inability to hear ordinary language, and thus, to speak it - to mean what we say. This inability to be the subject of one's words - which is the ability to speak common language and to enter or inhabit the human form of life - is the entire subject of The Claim of Reason. 


\section{Voice and Community}

From the beginning, Cavell calls into question our criteria - that is, our common agreement on, or rather in language, in "form of life" and, more precisely, the we at stake in "what we say when." What grounds the turn to ordinary language $e^{2}$ ? All that we have is what we say, and our agreements in language. We agree not on meanings but on usages, as Wittgenstein saw. One determines the "meaning of a word" by its uses. The search for agreement (asking "what would you say if...", as Austin constantly did) is grounded on something entirely other than meanings or the determination of speakers' "common sense." The agreement Austin and Wittgenstein speak of is in no way an inter-subjective agreement. It is as objective an agreement as possible. But what is this agreement? Where does it come from, and why accord it so much importance? This is the problem Cavell treats. Throughout his work, he asks: what allows Austin and Wittgenstein to say what they say about what we say? For Cavell, the radical absence of foundation to the claim to "say what we say" (first discovery of his) is not the mark of some lack of logical rigor or rational certainty (a second discovery) in the procedure (ordinary language philosophy) that starts off from this claim. This is what Wittgenstein means when speaking about our "agreement in judgments" and in language: it is founded only on itself, in the we. A discovery that is at once "simple and difficult".

We learn and teach words in certain contexts, and then we are expected, and expect others, to be able to project them into further contexts. Nothing insures that this projection will take place (in particular, not the grasping of universals nor the grasping of books of rules), just as nothing insures that we will make, and understand, the same projections. That on the whole we do is a matter of our sharing routes of interest and feeling, modes of response, senses of [...] of when an utterance is an assertion, when an appeal, when an explanation - all the whirl of organism Wittgenstein calls 'forms of life.' Human speech and activity, sanity and community, rest upon nothing more, but nothing less, than this. It is a vision as simple as it is

\footnotetext{
${ }^{2}$ See S. Laugier (2013) and S. Laugier, "Introduction to the French Edition of Must We Mean What We Say?", Critical Inquiry 37, No. 4 (Summer 2011), pp. 627-651.
} 
difficult, and as difficult as it is (and because it is) terrifying. (Cavell 1969: 52)

Cavell shows both the fragility and the depth of our agreements, and focuses on the very nature of the necessities that emerge for Wittgenstein from our life forms. The fact that our ordinary language is founded in life forms is not only a source of disquiet about the validity of what we do and say; it is the revelation of a truth about ourselves that we do not want to recognize: the fact that "I" am the only possible source of such validity.

To reject this, to try to erase skepticism, amounts to reinforcing it. This is what Cavell means by his famous proposition in The Claim of Reason that skepticism is lived, is a form of life. This is a new understanding of the fact that language is our form of life. Acceptance of this fact - which Cavell defines as the "the absence of foundation or guarantee for creatures endowed with language and subject to its powers and weaknesses, subject to their mortal condition" $^{3}$ - is thus not a consolation, a deliverance, but an acknowledgement of finitude and of the everyday. It is on this condition that one can regain "lost contact with reality": the proximity to the world and words broken in skepticism.

Cavell's originality indeed lies in his reinvention of the nature of language and in the connection he establishes between this nature (Übereinstimmung) and buman nature, finitude of life. It is in this sense that the question of language agreements reformulates the question of the human condition, and it is in this sense that acceptance of this natural condition goes hand-in-hand with acknowledgment of these (language) agreements. At stake here is acceptance of expression itself: to tolerate being expressive, meaningful.

The philosophical problem raised by ordinary language philosophy is thus double. First, as we have seen: by what right do we base ourselves on what we ordinarily say? And next: on what, or on whom do we base ourselves to determine what we ordinarily say? But - and this is the genius of Cavell's arguments in Must We Mean What We Say? (1969) and in The Claim of Reason - these two

\footnotetext{
${ }^{3}$ Stanley Cavell, Preface to the French edition of The Claim of Reason, Les voix de la raison. Paris: Le Seuil 1979.
} 
questions are but one: the question of the connexion of the I (my words) to the real (our world). That is to say, for Cavell as for Wittgenstein, the question of our criteria. In order to see this, let us return to his investigation of language agreements: "we share criteria by which we regulate our application of concepts, means by which, in conjunction with what Wittgenstein calls grammar, we set up the shifting conditions for conversation" (Cavell 1988:5). In the Investigations, Wittgenstein searches out and determines our criteria, which govern what we say. But who is he to claim to know such things? It is this absence of any foundation to the claim to know what we say that underlies the idea of criteria and defines a claim. The central enigma of rationality and the community is thus the possibility for me to speak in the name of others.

According to Cavell, this explains not only the shift from description to expression and confession, but above all, the very particular tone of the Investigations, which have something autobiographical about them - though a curious autobiography, which would also be our own.

It can seem sometimes that Wittgenstein has undertaken to voice our secrets, secrets we did not know were known, or did not know we shared. And then, whether he is right or wrong in a given instance, the very intention, or presumption, will seem to some outrageous. (Cavell 1979: 20)

It is this tone of confidence that brings Wittgenstein close to Rousseau and Thoreau for example, and more generally to the genre of autobiography, which in Wittgenstein's work substitutes for the philosophical treatise or the aphorism:

The writer has secrets to tell which can only be told to strangers. The secrets are not his, and they are not the confidences of others. They are secrets because few are anxious to know them; all but one or two wish to remain foreign. Only those who recognize themselves as strangers can be told them, because those who think themselves familiars will think they have already heard what the writer is saying. They will not understand his speaking in confidence. (Cavell 1972: 9293)

This brings us back to the voice and the question of the foundation of agreement: that is, the question of the nature of the $I$ - of my 
capacity to speak, and thus, to conform to shared criteria. It is not enough to invoke the community of shared forms of life; it remains to be seen what authorizes me (gives me title) to transform it.

When I remarked that the philosophical search for our criteria is a search for community, I was in effect answering the second question I uncovered in the face of the claim to speak for "the group" - the question, namely, about how I could have been party to the establishing of criteria if I do not recognize that I have and do not know what they are. [...] to emphasize that the claim is not that one can tell a priori who is implicated by me, because one point of the particular kind of investigation Wittgenstein calls grammatical is exactly to discover who. (Cavell 1979: 22)

That we agree in language is certainly not the end of the problem of skepticism, and conventionalism is not an answer to the questions asked here. Indeed, for Cavell it is crucial that Wittgenstein says that we agree in and not on language. This means that we are not agents of the agreement; that language as form of life precedes this agreement as much as it is produced by it and that this circularity constitutes an irreducible element of skepticism. A solution cannot be found in conventionalism, because convention does not constitute an explanation of the functioning of language, but an essential difficulty. The idea of convention does indeed mean something (in this sense, it is unavoidable): it registers the strength of our agreements and the extraordinary nature of our capacity to speak together. But convention cannot account for the real practice of language, and it serves instead to prevent us from seeing the naturality of language. As Cavell says:

since we cannot assume that the words we are given have their meaning by nature, we are led to assume they take it from convention; and yet no current idea of "convention" could seem to do the work that words do - there would have to be, we could say, too many conventions in play... We cannot have agreed beforehand to all that would be necessary. (Cavell 1979:31)

To agree in language means that language - our form of life produces our understanding just as much as it is the product of an agreement; that in this sense it is natural to us, and that the idea of convention is there to at once mimic and mask this necessity: "Underlying the tyranny of convention is the tyranny of nature," 
Cavell will say (Cavell 1979: 123). Here, Cavell's critique in This New Yet Unapproachable America of usual interpretations of "forms of life" through the formula "forms of life" (not simply forms of life), the form of life not only in its social dimension but in its biological dimension. Cavell insists on this vertical aspect of form of life, while recognizing the importance of the horizontal social agreement. Discussions of the latter (conventionalism) have occluded the force of the "natural" and biological sense of forms of life in Wittgenstein, defined in his mention of "natural reactions," "the natural history of humanity" (Cavell 1989: 41-2).

What is given in forms of life are not just our social structures and different cultural habits, but everything that has to do with "the specific strength and scale of the human body, senses and voice." The naturalness of language, its expressivity through vocalization and gestures, is as or even more essential than is its conventionality to the publicity of language - is forgotten or repressed, even in the metaphorization of voice.

Still I am not "by definition" representative of the human. The agreement can be broken. I can be excluded (or exclude myself) from the form of life, both linguistic and political. The possibility of disagreement is inherent even to the idea of agreement; from the moment I claim my representativeness, the risk is exclusion from form of life.

For Cavell, the question of the social contract underlies the question of language agreements, as his analysis of Rousseau at the beginning of The Claim of Reason shows. If I am representative I must have my voice in the common conversation. If my society is my expression it should also allow me to find my voice. But is this really the case? If others stifle my voice, speak for me, I will always seem to consent. One does not have a voice, one's own voice: it must be found so as to speak in the name of others and to let others speak in one's name. For if others do not accept my words, I lose more than language: I lose my voice.

We do not know in advance what the content of our mutual acceptance is, how far we may be in agreement. I do not know in advance how deep my agreement with myself is, how far responsibility for the language may run. But if I am to have my own voice in it, I 
must be speaking for others and allow others to speak for me. The alternative to speaking for myself representatively (for someone else's consent) is not: speaking for myself privately. The alternative is having nothing to say, being voiceless, not even mute. (Cavell 1979: 26)

The error is to see an alternative between private and public (this is the prejudice that underlies discussions of "the private language argument"). Cavell explodes this alternative. To not be public is not to be private: it is to be inexpressive. "Voiceless, not even mute." If I do not speak, it is not that there is something inexpressible, but that I have nothing to say, and this is not only about sharing a life form with others, but about being alive.

\section{Voice, Life, and Claim}

Our agreement (with others, with myself) is an agreement of voices: our übereinstimmen, says Wittgenstein.

That a group of human beings stimmen in their language überein says, so to speak, that they are mutually voiced with respect to it, mutually attuned top to bottom (Cavell 1979: 32)

Cavell thus defines an agreement that is not psychological or intersubjective, and which is founded on nothing other than the pure validity of a voice: my individual voice claims to be, is, a "universal voice." Claiming is what a voice does when it founds itself on itself alone in order to establish universal agreement - a claim that, as exorbitant as it already is, Cavell asks us to formulate in a yet more exorbitant manner: in place and stead of any condition of reason or understanding.

In Must We Mean What We Say? Cavell posed the question of the foundation of language in the Kantian terms of "universal voice", showing the proximity of Wittgenstein and Austin's methods to a paradox inherent to aesthetic judgment: basing oneself on $I$ in order to say what we say. Cavell refers to the well-known passage in $\$ 8$ of the Critique of Judgment. In aesthetic judgment, Kant leads us to discover "a property of our faculty of cognition that without this analysis would have remained unknown"; the "claim to universality" proper to judgments of taste, which make us "ascribe the satisfaction in an object to everyone" (Kant 2000: 99). Kant 
distinguishes the agreeable from the beautiful (which claims universal agreement) in terms of private versus public judgment. How can a judgment with all the characteristics of being private claim to be public, to be valid for all? Kant himself noted the strange, "disconcerting" nature of this fact, whose strangeness Wittgenstein took to the limit. The judgment of taste demands universal agreement, "and in fact everyone supposes this assent (agreement, Einstimmung)." What Kant calls the universal voice (allgemeine Stimme) supports such a claim. We hear this "voice" in the idea of agreement, übereinstimmen, the verb used by Wittgenstein when he speaks of our agreement in language (PI \$241-242). The universal voice expresses our agreement and thus our claim to speak in the name of others - to speak, tout court.

The question of the universal voice is the question of the voice itself and its arrogation - an individual voice claiming to speak in the name of others. What is, then, the status of the voice? This question only receives a response in A Pitch of Philosophy. The philosopher speaks with ordinary words, and nothing says that others will accept these - though the philosopher claims to speak for all. By what right?

- Who is to say whether a man speaks for all men?

Why are we so bullied by such a question? Do we imagine that if it has a sound answer the answer must be obvious or immediate? But it is no easier to say who speaks for all men than it is to speak for all men. And why should that be easier than knowing whether a man speaks for me? (Cavell 1969: xl)

Here we may think of one of the stakes of Austin's work: the method of ordinary language philosophy. It is difficult not to notice that there is an "unhappy" dimension, a dimension of failure in ordinary language philosophy, which is obsessed - at least in the case of Austin - with instances where language fails, is inadequate, inexpressive. Austin draws attention to the sexual connotations (which he says are perfectly "normal") of the terms he chooses to designate the different failures of performatives (misfires, abuses). The ever-possible failure of the performative defines language as a human and living activity, felicitous or infelicitous. 
One of the goals of ordinary language philosophy will thus be to determine the way or ways in which a statement can be infelicitous; failed; inadequate to the real. This can happen in a number of ways, for a statement may fail by being false, certainly, but also by being exaggerated, vague, inadequate, incongruous, inept, etc.: Austin likes to enumerate all the different possibilities, which expand the notion of false (and true) to all statements, including those one would have thought "exempt." Skepticism runs throughout our ordinary use of language, and this is the form the failure of language then takes. I am constantly tempted, or threatened, by inexpressiveness. ("Voiceless: not even mute.") The refusal of expression is also a refusal of the community of language in the sense in which the community would impose or represent the limits and constraints of language. Cavell brings Freud and Wittgenstein together in their shared awareness that disillusionment is a source of new errors, and that it never brings us closer to mastery of ourselves, our actions, or our words. Here again there is no secret to discover and the very idea of a secret masks this radical inadequacy, this absence of control over our speech, our voices, our lives.

Because the breaking of such control is a constant purpose of the later Wittgenstein, his writing is deeply practical and negative, the way Freud's is. And like Freud's therapy, it wishes to prevent understanding which is unaccompanied by inner change. [...] In both, such misfortune is betrayed in the incongruence between what is said and what is meant or expressed; for both, the self is concealed in assertion and action and revealed in temptation and wish. (ibid.: 72)

Whether through ordinary language philosophy or psychoanalysis, the examination of our statements does not give us more mastery over our lives or words. This is the final, radical shift operated by Cavell: language does not bring me mastery - to the contrary. This is why in defining, as Cavell does, ordinary language by voice - the voice of the I who speaks in the name of all others, in this arrogation of the voice that is the mark of all human expression one does not reconstitute a new subject, subject of speech, nor makes physical voice the mark of the human. Certainly my voice (from the first cry, alluded to at the beginning of The Claim, to the last breath, Cavell 1994: 125-6) is the first manifestation of me. But 
in his latest texts, Cavell rejects the idea of a metaphysics of presence in the concept of voice or speech. I am no more present in my voice than in my other works, actions, or possessions, and the human voice, like ordinary language, is suffused with the skepticism of The Claim of Reason.

\section{Voice and Dispossession}

I am more possessed by language than I possess it. This point, expressed in A Pitch of Philosophy, makes explicit an intuition from Must We Mean What We Say? about the source of skepticism: an impossibility of speaking the world that comes not from any (imaginary) distancing of the world, but from the refusal to mean.

What they had not realized what was they were saying, or, what they were really saying, and so had not known what they meant. To this extent, they had not known themselves, and not known the world. (Cavell 1969: 40)

Our (deliberate) distance from the world creates a fantasy: the fantasy of the private, of inexpressiveness - which becomes the very anxiety of the weight of expression.

So the fantasy of a private language, underlying the wish to deny the publicness of language, turns out, so far, to be a fantasy, or fear, either of inexpressiveness, one in which I am not merely unknown, but in which I am powerless to make myself known; or one in which what I express is beyond my control. (Cavell 1979: 351)

The question of privacy is transformed and becomes that of the fatality of meaning, or of my "fatedness" to signification. The problem is thus not meaninglessness or the impossibility of "making sense", but rather the fatality of expression.

The question, within the mood of the fantasy is: Why do we attach significance to any words and deeds, of others or of ourselves? [...] A fantasy of necessary inexpressiveness would solve a simultaneous set of metaphysical problems: it would relieve me of the responsibility for making myself known to others - as though if I were expressive that would mean continuously betraying my experiences, incessantly giving myself away; it would suggest that my responsibility for selfknowledge takes care of itself - as though the fact that others cannot know my (inner) life means that I cannot fail to. (id.) 
To understand that, as Wittgenstein said, language is life form (and not only our form of life) means accepting the naturalness of language, the fatality of signification. This is not easy to achieve. It is from here that skepticism in its various forms is born: the impossibility of accessing the world is a mask for my own refusal to bear signification, meaning, expression. From here, realism in its various forms is born - my claim to know or theorize the real is a mask for my refusing agency, contact, proximity with things. To mean, or to know what one means, would be first and foremost to place the sentence, to quote Wittgenstein, back in its "country of origin", its "natural milieu"; to recover the naturalness of language. This was the task of the ordinary language philosopher; as Wittgenstein says, "to bring words back from their metaphysical to their everyday use" (PI \$116). But I think the idea of life form goes beyond this imagery of a return to home [Heimat]. There is nothing to recover. There is no place like home, as Dorothy says. We are not agents of our language, but to use Emerson's phrase, "victims of expression".

Thus Cavell makes more precise in A Pitch of Philosophy what was sketched out at the end of The Claim of Reason concerning the essential passivity of the relation to the voice.

It is in recognizing this abandonment to my words, as if to unfeasible epitaphs, presaging the leave-taking of death, that I know my voice, recognize my words (no different from yours) as mine. (Cavell 1994: 126)

To be thus abandoned to language is indeed the opposite of what the concept of speech (active, living, etc.) would seem to imply. I am as active (and also as passive) in my voice as in, for example, my breathing or my exhalation, and the question is then no longer being able to access language, the community of speakers, or one's voice (horizontal forms of life); it is being able to bear precisely "the (inevitable) extension of the voice, which will always escape me and will forever find its way back to me." $(i d$.

And thus, what is unbearable is not the inexpressible or the impossibility of being expressive it is expression itself as life form, a life that is not mine anymore. The phantasm of the private disguises our fear of being public, "the terror of being expressive 
beyond our means," as a symmetrical fear of inexpressiveness (the idea of "private language."). This is indeed the question literature must face in its problematic relation to autobiography and confession, the question film faces most radically.

\section{Voice and Subjectivity}

A speech claims a voice. The subject is not a foundation; it is eternally claimed, absent, demanded. In redefining the subject through the subjectivity of language defined by voice, one situates the subject within naturalness (the voice as breath) and naked life: this is a subjectivity without subject. The dimensions of failure and vulnerability are not accidental or complementary to an essence of language. What must be brought out is not only the subject's fragility or plurality or obscurity, but also her essential passivity: the subject must support the voice, as it must action.

The subjectivity of language is then the impossible adequacy between a speaker and her voice or voices. Here the terror of absolute inexpressiveness and of absolute expressiveness, of total exposure, come together as two states of voicelessness.

I am led to stress the condition of the terror of absolute inexpressiveness, suffocation, which at the same time reveals itself as a terror of absolute expressiveness, unconditioned exposure; they are the extreme states of voicelessness. (Cavell 1997: 43)

The subjectivity of language is then the impossible adequacy between a speaker her voice or voices. We will note that this dissociation/dislocation of the voice and agent is at the heart of the different forms of expression in the human form of life:

On film the actor is the subject of the camera, emphasizing that this actor could (have) become other characters (that is, emphasizing the potentiality in human existence, the self's journeying), as opposed to theater's emphasizing that this character could (will) accept other actors (that is, emphasizing the fatedness in human existence, the self's finality or typicality at each step of the journey). In opera the relative emphasis of singer and role seems undecidable in these terms, indeed unimportant beside the fact of the new conception it introduces of the relation between voice and body, a relation in which not this character and this actor are embodied in each other but in which this voice is 
located in - one might say disembodied within - this figure, this double, this person, this persona, this singer, whose voice is essentially unaffected by the role. (Cavell 1994: 137)

One may also note that such dislocation of the voice is also at the heart of Cavell's autobiographical project, in Little Did I Know.

This second analyst and I eventually spent some time analyzing more or less informally my own writings. The simultaneous fear of inexpressiveness and of over-expressiveness is a recurrent topic in the material I had just decided to put aside as eluding completion by me, in its thesis form called The Claim To Rationality, in its revised and doubled form published as The Claim of Reason. (Cavell 2010: 140)

Cavell shows how film is the privileged medium for vulnerability and exposure, expressiveness and inexpressiveness. Film's capacity to put before us the expressiveness of the human, especially through women's expressions, defines the intimacy of film with the human life form. Cavell describes it as the threat/desire of inexpressiveness - fear of inexpressiveness, vs. terror of expressiveness, of total exposure - the polarization of inexpressiveness in two states of voicelessness, which is the concrete outcome of the fantasy of private language as criticized in the Philosophical Investigations, and of what Cavell calls, after Wittgenstein, Skepticism.

\section{References}

Cavell S., 1969. Must We Mean What We Say? New York: Scribner's. Cavell S., 1972. The Senses of $W$ alden. $2^{\text {nd }}$ edition 1992. Chicago: The University of Chicago Press.

Cavell S., 1979. The Claim of Reason. New York: Oxford University Press.

Cavell S., 1988. In Quest of the Ordinary. Chicago: The University of Chicago Press.

Cavell S., 1989. This New Yet Unapproachable America. San Francisco: North Point Press.

Cavell S., 1994. A Pitch of Philosophy. Cambridge: Harvard University Press. Cavell S., 2010. Little Did I Know: Excerpts from Memory. Cambridge: Harvard University Press. 
Kant 2000. Critique of the Power of Judgment, ed. Paul Guyer. New York:

Cambridge University Press.

Laugier S., 2007. "The Myth of the Outer: Wittgenstein's redefinition of subjectivity”. In: Moyal-Sharrock (Ed.) 2007, pp.151-173.

Laugier S., 2011. "Introduction to the French Edition of Must We Mean

What We Say?" Critical Inquiry 37 (4), pp. 627-651.

Laugier S., 2013. Why We Need Ordinary Language Philosophy. Chicago: Chicago University Press.

Moyal-Sharrock D. (ed.) 2007. Perspicuous Presentations: Essays on Wittgenstein's

Philosophy of Psychology. London: Palgrave.

Wittgenstein, L. 1970. Zettel. G.E.M. Anscombe and G.H. von Wright (eds).

Trans G.E.M. Anscombe. Berkeley: University of California Press. [Z]

Wittgenstein, L. 1980. Remarks on the Philosophy of Psychology / Bemerkungen über

Die Philosophie Der Psychologie, Vol. I, ed. G.E.M. Anscombe and G.H.

von Wright, tr. G.E.M. Anscombe, Oxford: Blackwell. [RPP I]

Wittgenstein, L., 2001. Philosophical Investigations / Pbilosophische Untersuchungen,

tr. G.E.M. Anscombe, 3rd Edition. Oxford: Blackwell. [PI]

\section{Biographical Note}

Sandra Laugier is Professor of Philosophy at Université Paris 1 Panthéon-Sorbonne, and Senior member of the Institut Universitaire de France. She is the translator of Stanley Cavell's work in French and specializes in Ordinary Language Philosophy (Wittgenstein, Austin, Cavell), American Philosophy, Gender studies, and Ethics of care. She is the author of many publications in French, English, Italian, German, of which Wittgenstein, les sens de l'usage (2009); Wittgenstein, Le mythe de l'inexpressivité (2010); Why We Need Ordinary Language Philosophy (2013). Recommencer la philosophie, Cavell et la philosophie américaine (2014). Her edited volumes include: La voix et la vertu, variétés du perfectionnisme moral (2010); J. L. Austin et la philosopbie du langage ordinaire (ed. with C. Alsaleh) (2011); Tous vulnérables, le care, les animaux et l'environnement (2012). 